\title{
Hydrometeorology of Anthropogenic Erosion in the Metropolitan Region of São Paulo
}

\author{
Maria del Carmen Sanz Lopez ${ }^{\circledR}$, Augusto José Pereira Filho ${ }^{\circledR}$, Jorge Luiz Diaz Pinaya ${ }^{\circledR}$ \\ Departamento de Ciências Atmosférica do Instituto de Astronomia, Geofísica e Ciências Atmosféricas da Universidade de São \\ Paulo, São Paulo, Brazil \\ Email: maria.d.c.s.lopez@gmail.com, augusto.pereira@iag.usp.br, jorge.pinaya.usp@gmail.com
}

How to cite this paper: Lopez, M.delC.S., Filho, A.J.P. and Pinaya, J.L.D. (2021) Hydrometeorology of Anthropogenic Erosion in the Metropolitan Region of São Paulo. Journal of Environmental Protection, 12, 1234-1253.

https://doi.org/10.4236/jep.2021.1212073

Received: December 4, 2021

Accepted: December 28, 2021

Published: December 31, 2021

Copyright $\odot 2021$ by author(s) and Scientific Research Publishing Inc. This work is licensed under the Creative Commons Attribution International License (CC BY 4.0).

http://creativecommons.org/licenses/by/4.0/

\begin{abstract}
Erosive processes play an important role in environmental degradation. Rain is the main erosive agent in the Metropolitan Region of Sao Paulo. This study characterized the erosion events caused by precipitation leveraging the accumulated daily precipitation estimate generated by the Climate Prediction Center Morphing Method (CMORPH) and integrating the surface telemetric network using the Statistical Objective Analysis method (SOAS). From the Civil Defense database, 400 events were identified in the Metropolitan region of Sao Paulo (MRSP) area between 2000 and 2013 and, of these, 3 were chosen to carry out meteorological and climatological analyses. In an initial observation, $58 \%$ of them were found to occur in summer. Two regions with the highest number of erosion events were observed, in the Serra do Mar and Serra da Cantareira. In the Serra do Mar core, the municipality of São Bernardo do Campo was the one with the greatest amount of erosion. Precipitation volumes were estimated for accumulations of 30 minutes, 1 day, 1 month, and 1 year. The results, from the 3 events, indicate accumulated precipitation in 30 minutes from $10 \mathrm{~mm}$ to $19.8 \mathrm{~mm}$, daily from $30.8 \mathrm{~mm}$ to $69.5 \mathrm{~mm}$, and 1 month from $369.7 \mathrm{~mm}$ to $742.5 \mathrm{~mm}$, and 1 year (2010) from $1712.9 \mathrm{~mm}$ to $1961.8 \mathrm{~mm}$. In these events, it was noted that there were heavy rains in December 2009 and January 2010. It was also noted that the CMORPH and SOAS identify the rain events found by the São Paulo meteorological radar. The meteorological analyzes of the events based on images from the São Paulo meteorological radar and the Meteosat-9 satellite indicate that the active precipitation systems are associated with cold fronts, instability lines, and isolated convection.
\end{abstract}

\section{Keywords}

Hydrometeorology, Anthropogenic Erosion, CMORPH, SOAS 


\section{Introduction}

A large part of the Brazilian population lives in cities, and human-caused environmental impact is visible [1]. The disorderly occupation of urban space, for example: with the waterproofing of soils, and buildings and the paving of traffic routes, cause changes in the hydrological cycle [2] and [3], reducing the area of water infiltration into the soil.

Soil erosion is a natural process and is present in the planet's dynamics, altering its terrains and landscapes. With direct and/or indirect human actions, this process of soil degradation is accelerated [4].

The occurrence of erosion in cities can materialize in the most diverse ways, but it is almost always associated with the removal of vegetation and manifests itself in rainy periods when the soil is very saturated. Furthermore, the lack of urban planning and the expansion of occupation of risk areas make the problem even greater, which highlights the fact that the issue is not only geomorphological but above all socioeconomic.

Precipitation associated with geological and physiographic characteristics is one of the main elements for the initiation of water erosion processes. Water erosion is the transport of soil particles by the action of water. The detachment of particles from the soil occurs due to the kinetic energy of the impact of raindrops, or by the washing of running water by laminar or turbulent flow [5] and [6].

As long as the water infiltration rate is lower than the surface supply rate, it accumulates on the surface, in irregularities and depressions in the soil, forming puddles. Only when surface storage is complete does surface runoff occur. Surface runoff represents the portion of the surface water supply that is neither absorbed by the soil nor contained by the surface but rather displaces. Runoff, in general, starts as laminar flow and tends to clear the soil surface and as it accelerates and gains strength it becomes a linear flow forming channel [5].

Depending on the characteristics and severity of the erosion, it receives a name. Laminar erosion occurs when there is uniform wear of the topsoil [6]. Linear erosion occurs when surface runoff is concentrated and based on its severity will call gutter, furrow, ravine, or gully [6].

Soil susceptibility is influenced by soil erodibility and rainfall erosivity [7] and [8]. Soil erodibility will depend on the physical and chemical properties of the soil, such as the percentage of clay, silt, and sand that compose it; porosity; density; and stability of its aggregates [9]. The erosivity of rain will depend on the characteristics of the rain, such as speed of fall; raindrop size; and rainfall intensity [8].

Erosion causes soil loss when runoff transports soil sediment from one location to another. The sediments when transported to watercourses cause siltation and pollution [10]. Where these sediments are removed, we observe ditches opened, terrain instability, and other problems.

Precipitation events are associated with mesoscale and synoptic-scale meteo- 
rological systems. This research aims to estimate precipitation volumes and identify the precipitation systems associated with them. It also seeks to demonstrate the reliability of the Climate Prediction Center Morphing Method (CMORPH) and the Statistical Objective Analysis method (SOAS) to determine the occurrence of rainfall and its volumes more broadly [11], as the CMORPH data are measured worldwide by satellite and you have the data for all of Brazil. Precipitation volumes were obtained using data from $\mathrm{CMORPH}$, which integrated with the telemetric network of surface rain gauges of the National Water Agency (NWA) by SOAS, resulting in more reliable data. The most active precipitating systems in the Metropolitan region of Sao Paulo (MRSP) are isolated convection (IC), sea breeze (SB), instability lines (IL), scattered precipitation bands (SPB), and cold fronts (CF) [12] [13] and [14].

Erosion sites are generally the lowest point on the ground, the end of slopes and riverbanks, for example. At the end of the runoff course where soil degradation becomes easier.

Civil Defense is an entity that works with prevention and emergency assistance in case of disasters. It also promotes preventive, care, and recovery actions. Your job is to avoid or minimize the consequences of accidents or natural or technological disasters. It works with other bodies, such as Geographical Institute, mapping risk areas both in the state of São Paulo and in the MRSP and developing warning systems, recording erosion events, among other activities.

In the MRSP, the main active erosive agent is pluvial (rain). Precipitation events are associated with mesoscale and synoptic-scale meteorological systems. It is in summer that more rain events occur and consequently more erosion events. It is interesting to check the rainfall history for places prone to erosion.

This study aimed to verify the reliability of the CMORPH and the SOAS, to determine the day and time of a probable rain event that generated the erosion event and its precipitated volumes; characterize the hydrometeorology of anthropogenic erosion in the MRSP.

\section{Study Area}

The study area is the MRSP, it is located in the Southeast region of Brazil and lies between the latitudes of $23^{\circ} \mathrm{S}$ and $24^{\circ} \mathrm{S}$ and between the longitudes of $45.9^{\circ}$ $\mathrm{W}$ and $47.1^{\circ} \mathrm{W}$ and is crossed by the Tropic of Capricorn. Its climate varies from tropical to subtropical [15], the study area is shown in Figure 1.

\section{Methods}

400 erosion records were acquired from the Civil Defense for the period 2000 to 2013. These events were distributed over the study area, and a monthly distribution graph of the occurrence of erosion events was made. Then, 3 events were selected for analysis of accumulated precipitation, meteorological and climatological estimates.

These 3 events obeyed a selection pre-condition which was: to have the data referring to CMORPH and SOAS in the year of occurrence of the event and the 


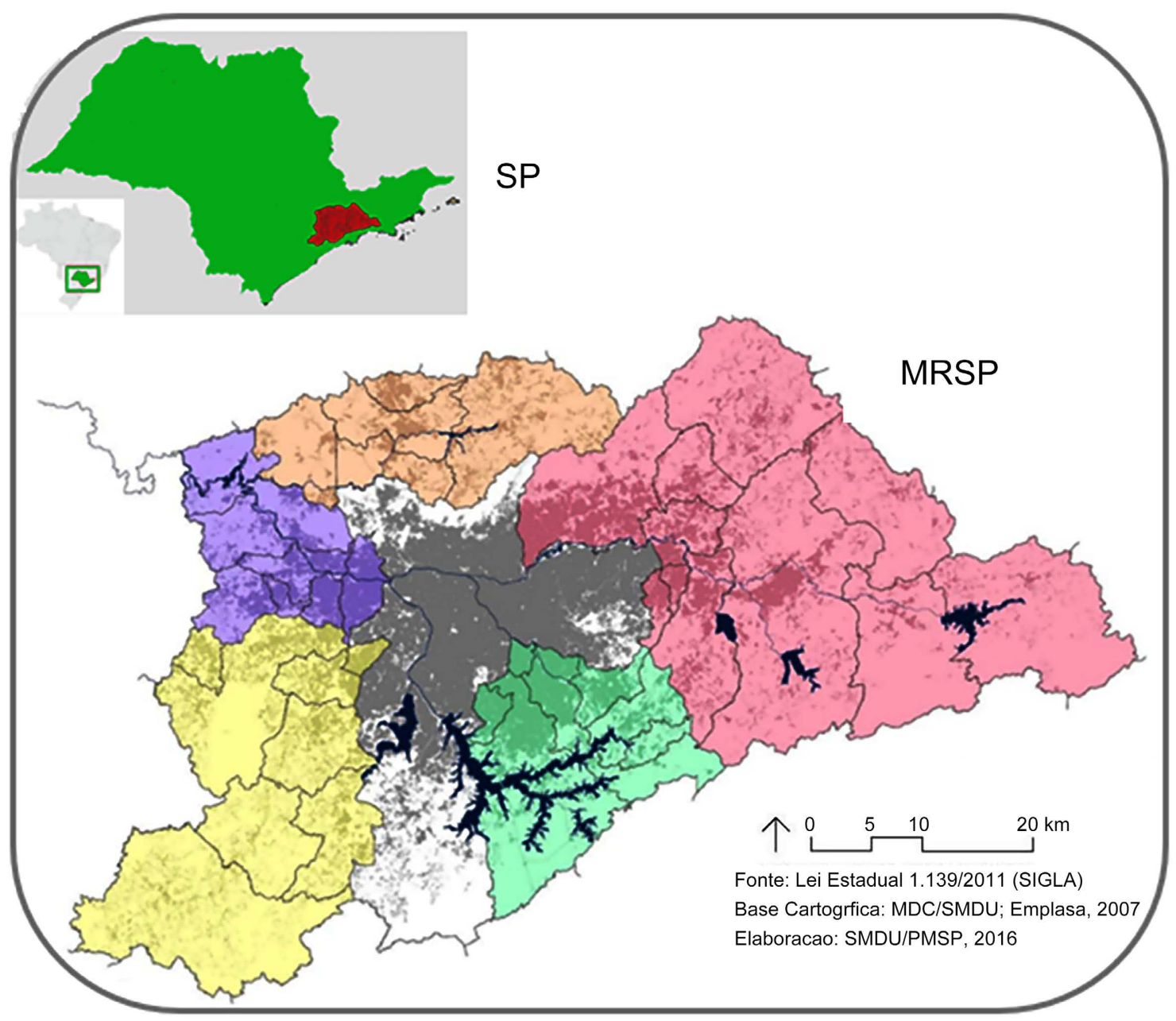

Figure 1. The study area of erosion events. Metropolitan Region of São Paulo, located in the state of São Paulo, Brazil. Source: State law 1.139/2011 (SIGLA), Cartographic Base MDC/SMDU; Emplasa, 2007.

year before the event; have a rain report from the São Paulo Weather radar (SPWR) on the rain date determined by the CMORPH and on that same date have satellite images (Meteosat-9) that identify the meteorological conditions for the existence of rain.

\subsection{Precipitation Estimate by the CMORPH Method and by the SOAS Method}

Precipitation estimation quantification based on satellite measurements is an important product and used worldwide for hydrometeorological applications such as weather and climate monitoring and water resources management [16]. $\mathrm{CMORPH}$ is a product that estimates precipitation with high spatiotemporal resolution through satellite measurements. This method allows to quantify the precipitation estimate with a temporal resolution of 30 minutes and spatial in an $8 \mathrm{~km} \times 8 \mathrm{~km}$ cell [17].

With the integration of data from CMORPH and data from NWA's rainfall network using the SOAS method, the error variance is reduced and more robust 
data are obtained. The precipitation estimate for these methods is determined every $8 \mathrm{~km}$. The data from CMORPH and the rainfall network are integrated every 24 hours, from $7 \mathrm{am}$ of one day to 7 am of the previous day. In Figure 2 there is a scheme that guides us in the integration of the CMORPH data with the pluviometer data.

The calculation of the precipitation estimates is obtained for SOAs by applying Equations (1) and (2);

$$
\begin{gathered}
P_{a}\left(x_{i}, y_{i}\right)=P_{b}\left(x_{i}, y_{i}\right)+\sum_{k=1}^{K} W_{i k}\left[P_{o}\left(x_{k}, y_{k}\right)-P_{b}\left(x_{k}, y_{k}\right)\right] \\
\sum_{k=1}^{K} W_{k}\left[\rho_{i k}+\varepsilon_{i}^{2}\right]=\rho_{i o}
\end{gathered}
$$

where

$P_{a}\left(x_{i}, y_{i}\right)=$ precipitation analyzed at the point where erosion event " $i$ " occurred;

$P_{b}\left(X_{i}, Y_{i}\right)=$ precipitation estimated with $\mathrm{CMORPH}$ at the point where erosion event " $\hat{i}$ " occurred;

$P_{o}\left(x_{k}, y_{k}\right)=$ precipitation measured by the rain gauge at a point $k, K$ can be used for rain gauges;

$P_{b}\left(x_{k}, y_{k}\right)=$ precipitation estimated with CMORPH at point $k$,

$W_{i k}=$ a posteriori weight, when you have 2 or more rain gauges, the weight of each will depend on the distance to point " $i$ ";

$K=$ number of rain gauges used;

$\left(x_{i}(k), y_{i}(k)\right)=$ coordinates $(\mathrm{km})$ from point $i$ to $(k)$;

$\rho_{i k}(i o)=$ correlation of the error of the measurements of the rain gauges $i$ and $k(i$ and $o)$;

$\varepsilon_{i}^{2}=$ normalized measurement error. Unit: $\mathrm{mm}$.

Georeferenced coordinates (latitude and longitude) are used in decimals. From the daily precipitation estimate from CMORPH and SOAS, monthly estimates of selected events were calculated, and a comparison was made with monthly precipitation data from the USP Weather Station (USP WS) in the years 2009 and 2010 [18].

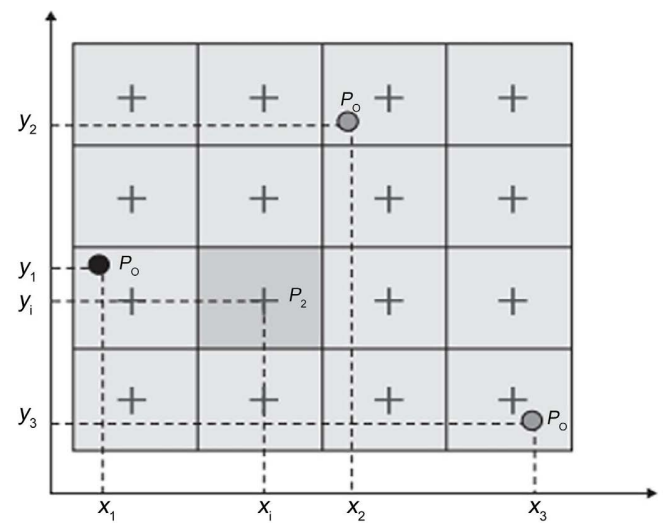

Figure 2. Scheme for the interpolation of NWA pluviometers with the CMORPH cell at the point where the erosion event occurred $(\mathrm{Pa})$. Source: [17]. 


\subsection{Precipitation Estimate for Every 30 Minutes with CMORPH and SOAS}

With the geographic coordinates of the erosion events, the coordinates of the CMORPH cell were obtained for the extraction of the daily accumulated precipitation estimate and the geotechnical characteristics. To determine the day on which the rain event that generated the erosion event occurred, the volume of accumulated precipitation in the 30 days preceding the erosion event was analyzed. Once the day with the highest precipitation was determined, the spacetime analysis was carried out with the CMORPH at intervals of 30 minutes to determine the time of rain and the precipitation values. The weighted adjustment factor was calculated by Equation (2) to obtain the respective precipitation values for the SOAS at intervals of 30 minutes, since the SOAS data are obtained every 24 hours.

$$
\mathrm{SOAS30} \min _{\mathrm{h}}=F_{\text {ap }} \cdot \mathrm{SOAS}_{\text {diary }}
$$

where

SOAS30 $\min _{\mathrm{h}}$ : SOAS accumulated precipitation estimate 30 minutes for a given time $(\mathrm{h})$;

$$
F_{\text {ap }}=\frac{\text { CMORPH30 } \text { min }_{\mathrm{h}}}{\sum_{1}^{48} \mathrm{CMORPH} 30 \mathrm{~min}}=\text { Weighted adjustment factor ; }
$$

CMORPH30 $\min _{h}$ : estimate of accumulated precipitation from CMORPH 30 minutes for a given time $(\mathrm{h})$;

$\sum_{1}^{48}$ CMORPH30 min : sum of accumulated precipitation estimates every 30 minutes of the whole day;

SOAS $_{\text {diary }}$ : daily accumulated precipitation estimate adjusted by SOAS.

It was verified whether the analyzed data and period corresponded to a rain event determined by the SPWR and if there were meteorological systems detected by the Meteosat- 9 satellite. For the meteorological analysis, the images of Meteosat-9 were analyzed on the specified day and time, and the active precipitating systems were determined.

\subsection{São Paulo Weather Radar (SPWR)}

The coverage of the SPWR is $240 \mathrm{~km}$. It is installed at the Ponte Nova dam at the head of the Tietê River in the municipality of Biritiba Mirim. The SPWR is owned by the Department of Water and Electric Energy. MRSP is covered by it and is an S-band radar [19].

From the SPWR, the existence of a rain event report on predetermined dates with the CMORPH was verified. Its records show the start, maximum, and end times of the rain. The accumulated values were observed.

\subsection{Satellite Meteosat-9}

The Meteosat-9 satellite images are made available every 15 minutes and provided by the Center for Weather and Climate Studies of the National Institute 
for Space Research. This satellite provides data for weather forecasting and climate surveys. It is operated jointly with the European Space Agency and the European Organization for the Exploitation of Meteorological Satellites. It has the property of recovering the temperature of the sea surface. The images are obtained from sensors that measure the longwave radiation emitted by the tops of clouds which processed highlight the tops with temperatures greater than $-80^{\circ} \mathrm{C}$. Temperatures above $-30^{\circ} \mathrm{C}$ are represented in shades of black bank gradients, the shades in white indicate clouds and those in black indicate their absence. The images used are from the CH-9 channel (SPW 10.8) infrared at a frequency of $10.8 \mu \mathrm{m}$ [20]. Figure 3 shows the infrared channel image of the Meteosat-9 satellite from 1830 UTC on 02/0/2010.

\section{Results and Discussion}

In the MRSP, 400 erosion events that occurred between 2000 and 2013 were identified, data were acquired from Civil Defense records and their distribution is shown in Figure 4. In this distribution, two cores with the highest concentration of erosion events were identified. The Serra do Mar nucleus, where the municipality of São Bernardo do Campo (SBC) had the most events, and the Serra da Cantareira nucleus, where the municipality of Caieiras was most affected.

The distribution of 400 erosion events in the months of the year from 2000 to 2013 is shown in Figure 5. Note that erosion events occurred mostly in the summer with 232 events (about 58\%), followed by autumn with 72 events, spring with 64 events, and winter with only 32 events. The rain in this region causes many environmental disasters, and as we have seen most rains occur in the summer.

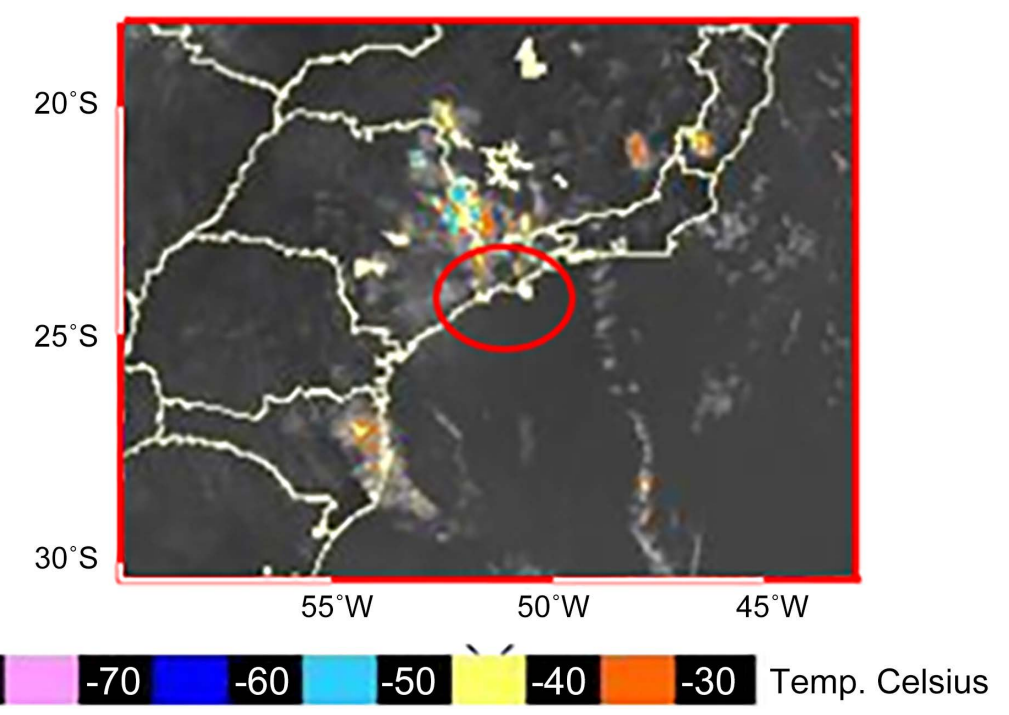

Figure 3. Infrared channel image of the Meteosat-9 satellites from 1830 UTC of 02/03. The geopolitical and geographic contours are indicated. The red circle indicates the area of the MRSP. Color scale indicates brightness temperature $\left({ }^{\circ} \mathrm{C}\right)$. Source: Adapted from [21]. 


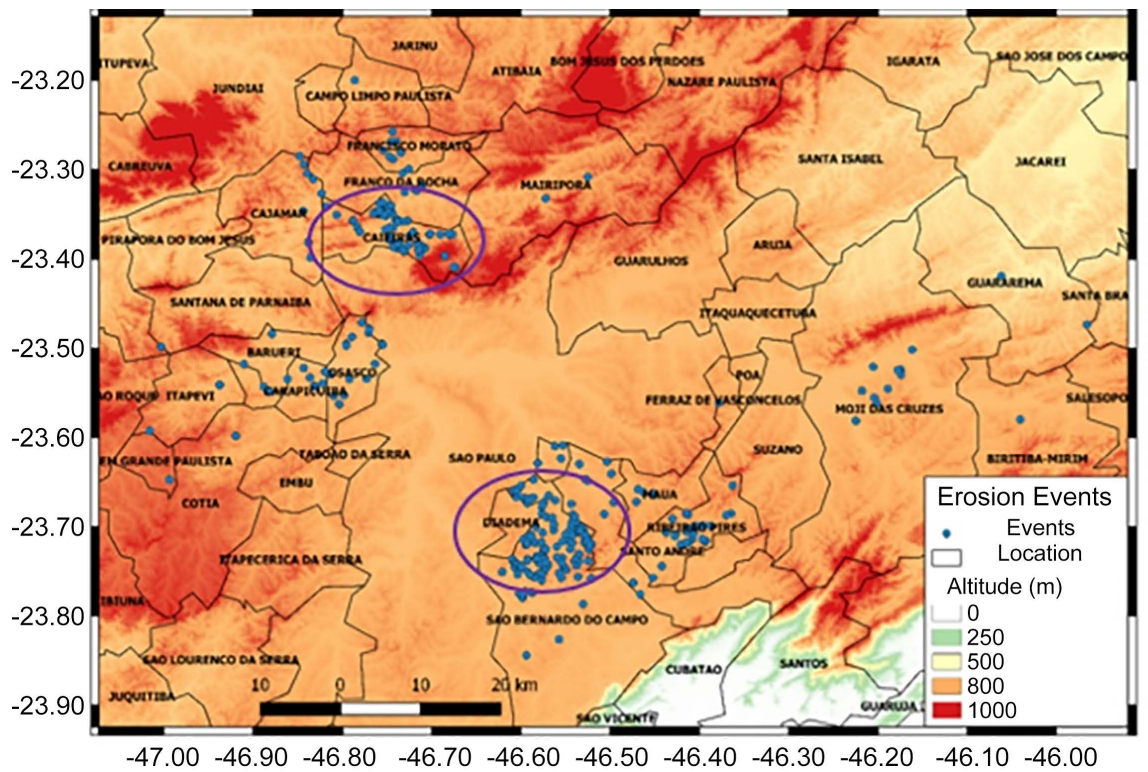

Figure 4. Image of the distribution of erosion events that occurred between 2000 and 2013 in the municipalities of the MRSP. The figure indicates the geopolitical and geographic contours, with the georeferenced points represented by blue circles. The color scale indicates the altitudes in the MRSP. The scale of distances in $\mathrm{km}$ is also indicated. The purple circles highlight the concentration of events, in the city of São Bernardo do Campo in the Serra do Mar core and the city of Caieiras and its surroundings the core of Serra da Cantareira.

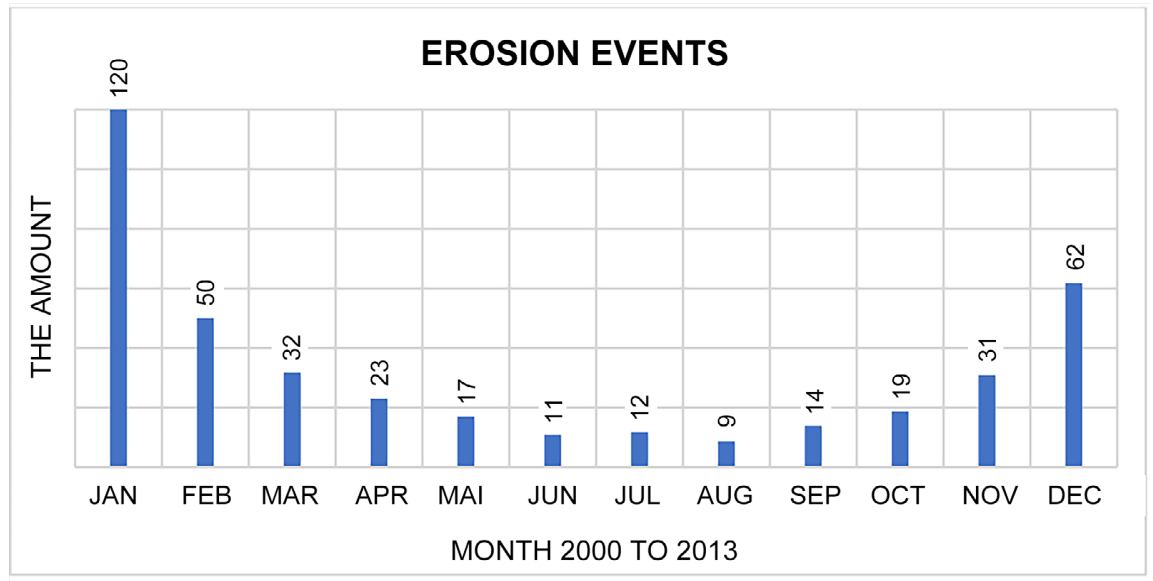

Figure 5. Distribution of 400 erosion events that occurred in the MRSP area over the months of the year, for the period 2000 to 2013.

For the meteorological and climatological analyzes of the 3 selected events, we started with the geographic coordinates (given), Table 1 and Figure 6, and the coordinates of the USP WS, which were used for climatological comparison. Based on the coordinates, it was verified that the events are in the municipality of São Bernardo do Campo.

\subsection{Hydrometeorological Analysis}

The historical series of precipitation estimates for the 30 days before the erosion 
event is shown in Figure 7. This series is shown with data from CMORPH and SOAS. The yellow bars highlight the volume that generated the erosive process in SOAS. The estimated volumes of precipitation accumulated in 30 days are shown in Table 2.

Table 1. The table indicates the geographic coordinates of the 3 erosion events analyzed, as well as the geographical coordinates of the USP WS on the last line.

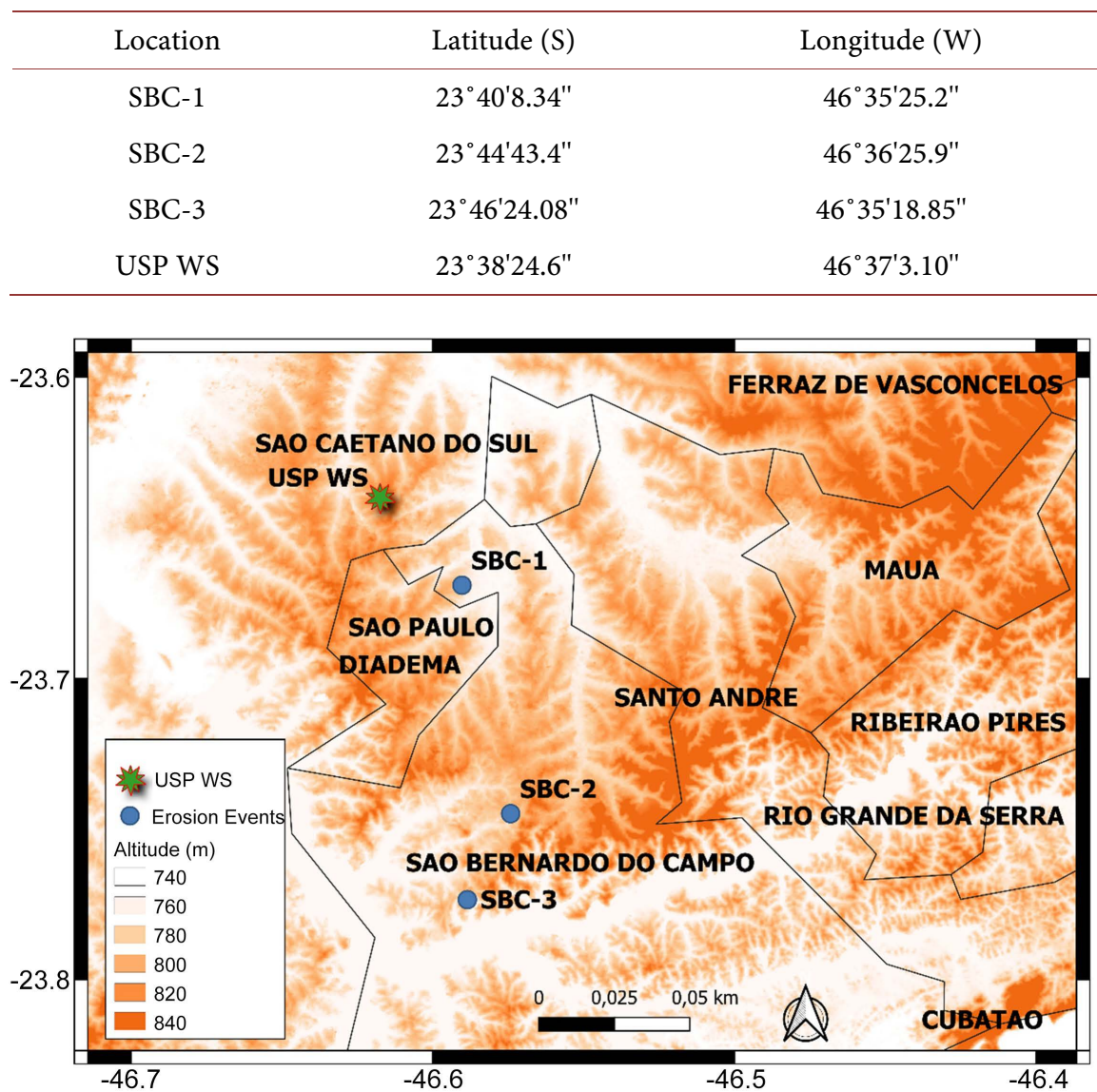

Figure 6. Map of the location of erosion events and USP WS.

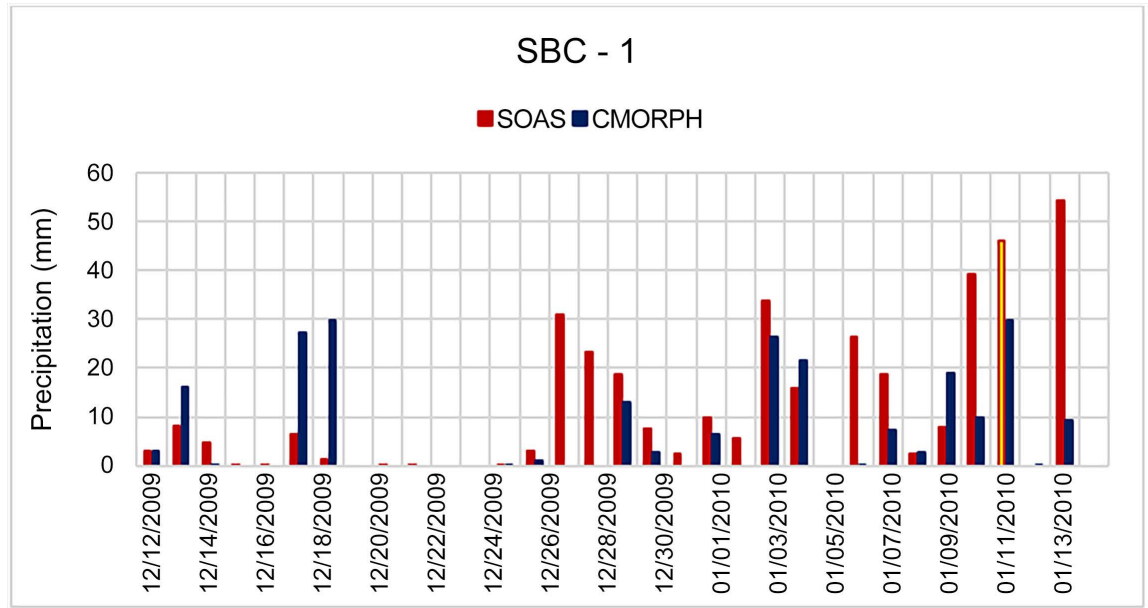

(a) 


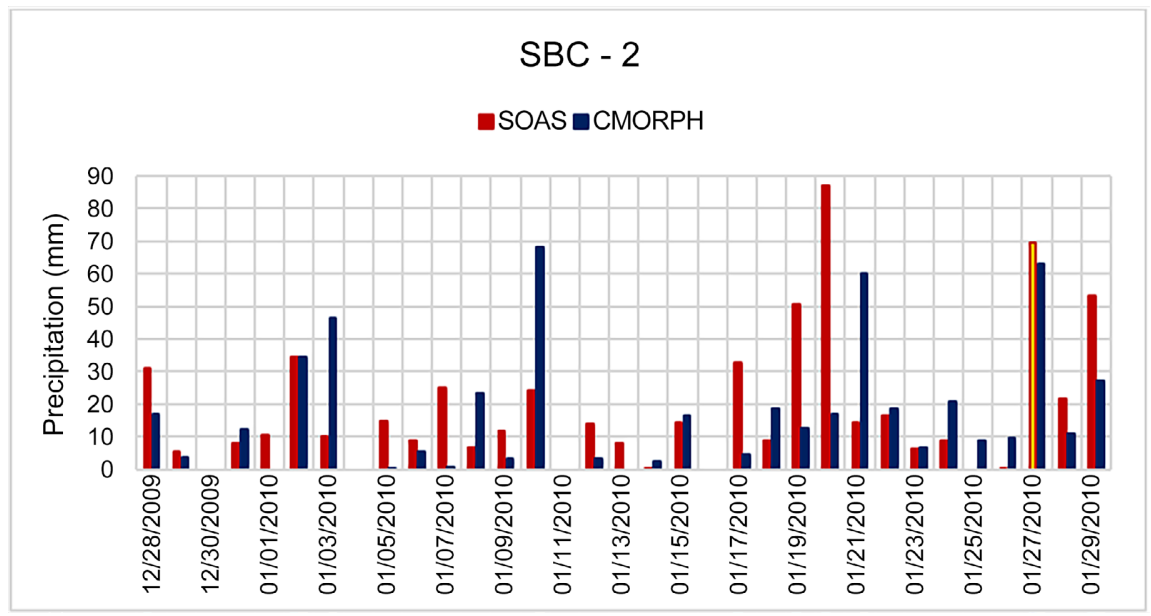

(b)

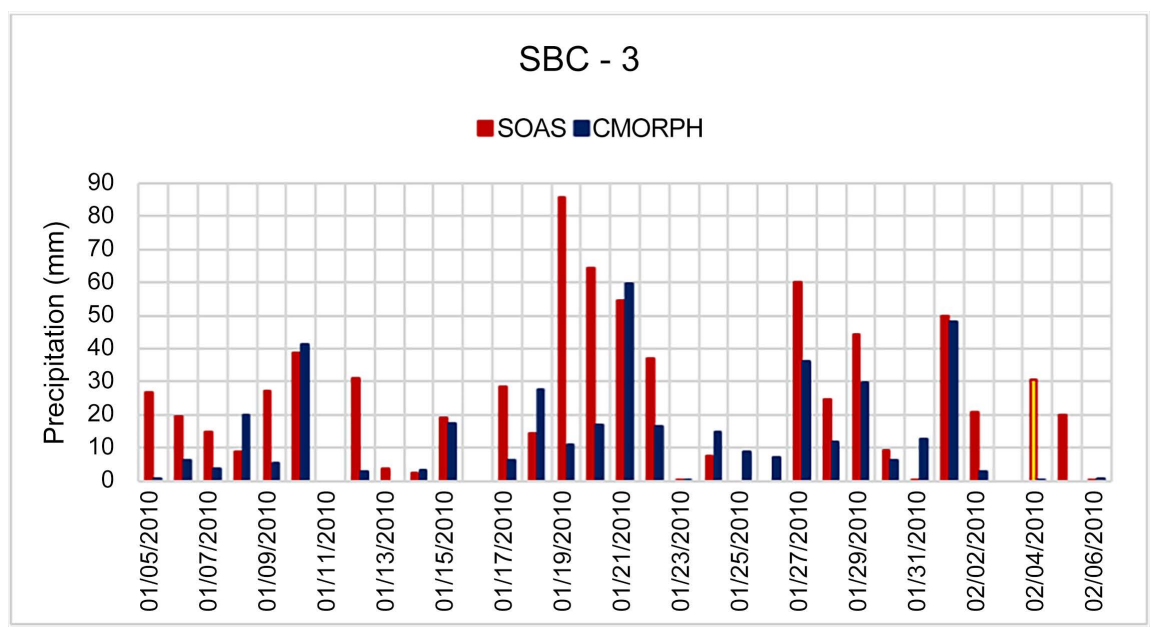

(c)

Figure 7. Historical series of the 3 erosion event sites, 30 days before the event, SOAS values in red and CMORPH values in blue. SBC-1 (a) erosion event on 01/12/2010; SBC2 (b) erosion event on 01/28/2010; and SBC-3 (c) erosion event on 02/05/2010. The yellow bars are the volume that generated the erosive process in SOAS.

Table 2. Precipitation volumes accumulated in the 30 days before the erosion event.

\begin{tabular}{ccc}
\hline \multirow{2}{*}{ Location } & \multicolumn{2}{c}{ Precipitation in the 30 days prior to the erosion event $(\mathrm{mm})$} \\
\cline { 2 - 3 } & CMORPH & SOAS \\
\hline SBC-1 & 225.7 & 369.7 \\
SBC-2 & 487.3 & 543.8 \\
SBC-3 & 416.8 & 742.5 \\
\hline
\end{tabular}

Values estimated by CMORPH are lower than those estimated by SOAS. The integration of satellite measurements with pluviometer measurements, in these cases, increases the estimated values of precipitation. It is observed that in Figure 7 (a) the rains start to become frequent from $12 / 26 / 2009$, and with high accumulated volumes. Figure 7 (b) shows rainfall with varying volumes in the 30 
days before the erosion event, and on 01/27/2010 an estimated volume accumulated by SOAS of about $70 \mathrm{~mm}$. On the other hand, in Figure 7(c) there are frequent rains from $01 / 05 / 2010$ to $02 / 04 / 2010$, the probable date of rain that must have caused the erosion event recorded on 02/05/2010. In all places, the soil was already saturated when the erosion took place.

Precipitation estimates on the day of and 2-days prior, with SOAS, are shown in Table 3. The dates of the rain event that caused each erosion event were obtained. The rain events occurred 1 to 3 days before the erosion event was registered by the Civil Defense, as shown in Table 4.

Once the date of the rain event was determined, the precipitation estimate values were verified every 30 minutes with the $\mathrm{CMORPH}$, and the corresponding SOAS value was calculated every 30 minutes. Based on the values found, the graphs in Figure 8 were drawn, which provide the period of each rain event and the estimated volumes

You see 3 distinct episodes of rain. In Figure 8(a) there is a peak of rain and followed by a decrease in it until extinction. In Figure $8(\mathrm{~b})$ the rain increases in volume to a peak at 1530 UTC on 01/26/2010 and decreases its volumes for a long time and towards extinction. In Figure 8(c) there is rain with a high value $(\sim 15.5 \mathrm{~mm})$ for one hour.

With the date and time of the rain determined, the existence of a rain report from the SPWR, Table 5, and the existence of satellite images confirming the event, Figure 9. With the information from the SPWR and the satellite images, a meteorological analysis of the rain event was carried out.

Table 3. Precipitated estimated volumes on the day of the event and the 2 previous days. Values estimated by SOAS, and determination of the day of the rain event that caused the erosion event.

\begin{tabular}{cccccc}
\hline Location & $\begin{array}{c}\text { Erosion Event } \\
\text { Date }\end{array}$ & \multicolumn{5}{c}{$\begin{array}{c}\text { Precipitation accumulated on } \\
\text { the day }\end{array}$} & $\begin{array}{c}\text { Rain Event } \\
\text { Date }\end{array}$ \\
\hline SBC-1 & $01 / 12 / 10$ & 12 & 11 & 10 & $01 / 11 / 10$ and $01 / 12 / 10$ \\
SOAS (mm) & & 54.2 & 0.0 & 46.0 & \\
SBC-2 & $01 / 28 / 10$ & 28 & 27 & 26 & $01 / 26 / 10$ \\
SOAS (mm) & & 21.5 & 69.5 & 0.4 & \\
SBC-3 & $02 / 05 / 10$ & 05 & 04 & 03 & $02 / 03 / 10$ \\
SOAS (mm) & & 19.9 & 30.8 & 0.0 & \\
\hline
\end{tabular}

Table 4. Summary of analyzed erosion events. The 1st column identifies the location of the erosion event; on the $2 \mathrm{nd}$, the date on which the erosion event occurred; on the 3rd date of the probable rain event that generated the erosion.

\begin{tabular}{ccc}
\hline Location & Erosion Event Date & Rain Event Date \\
\hline SBC-1 & $01 / 12 / 10$ & $01 / 11 / 10$ \\
SBC-2 & $01 / 28 / 10$ & $01 / 27 / 10$ \\
SBC-3 & $02 / 05 / 10$ & $02 / 03 / 10$ \\
\hline
\end{tabular}


Table 5. The day and time of the onset of rain and its duration are indicated. Local rain is by the SOAS method.

\begin{tabular}{ccccc}
\hline Location & $\begin{array}{c}\text { Start of rain } \\
\text { SPWR (UTC) }\end{array}$ & $\begin{array}{c}\text { Start of local rain } \\
\text { (UTC) }\end{array}$ & $\begin{array}{c}\text { Duration of } \\
\text { local rain }(\mathrm{h})\end{array}$ & $\begin{array}{c}\text { Duration of rain } \\
\text { SPWR (h) }\end{array}$ \\
\hline SBC-1 & $01 / 11-1418$ & $01 / 11-2030$ & 7.5 & 16.0 \\
SBC-2 & $01 / 27-1314$ & $01 / 27-1330$ & 11.5 & 17.0 \\
SBC-3 & $02 / 03-1742$ & $02 / 03-1830$ & 1.0 & 6.5 \\
\hline
\end{tabular}

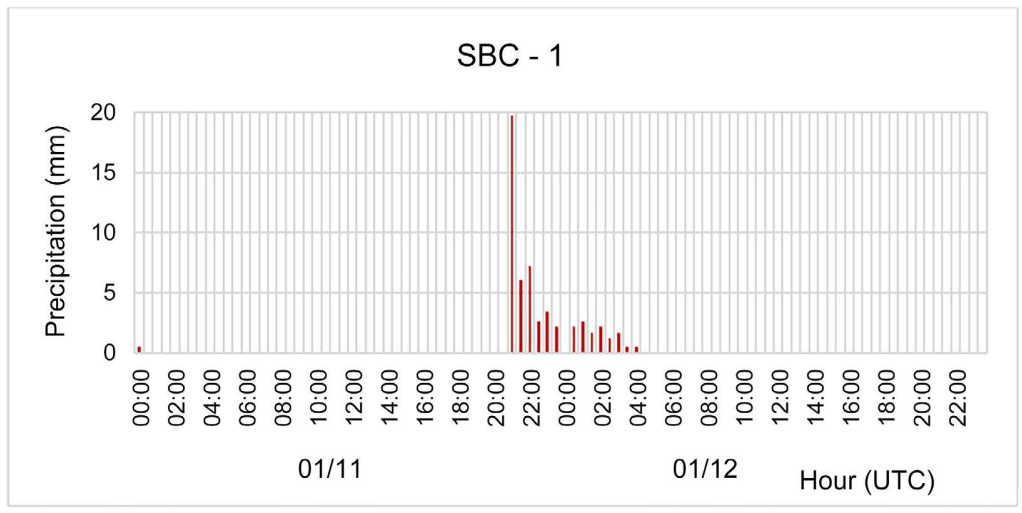

(a)

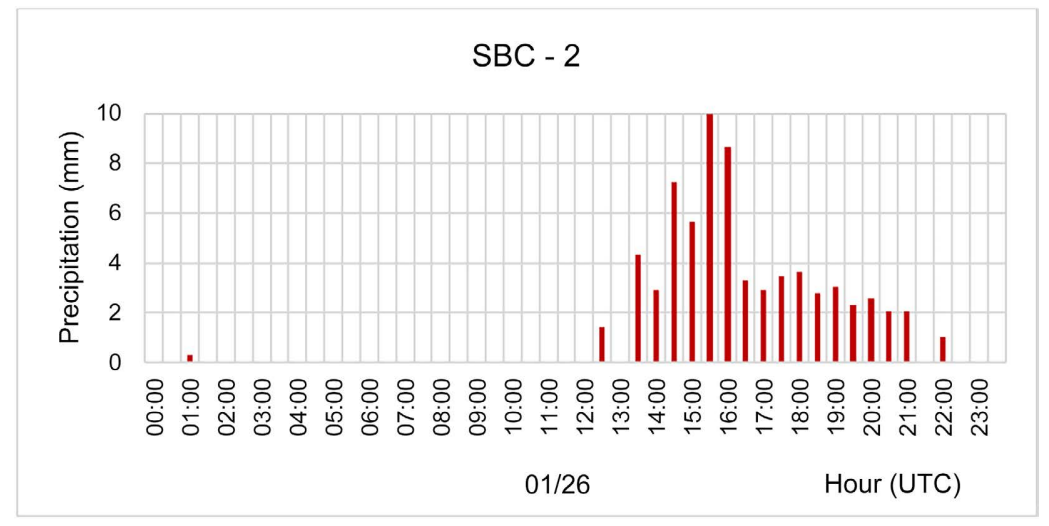

(b)

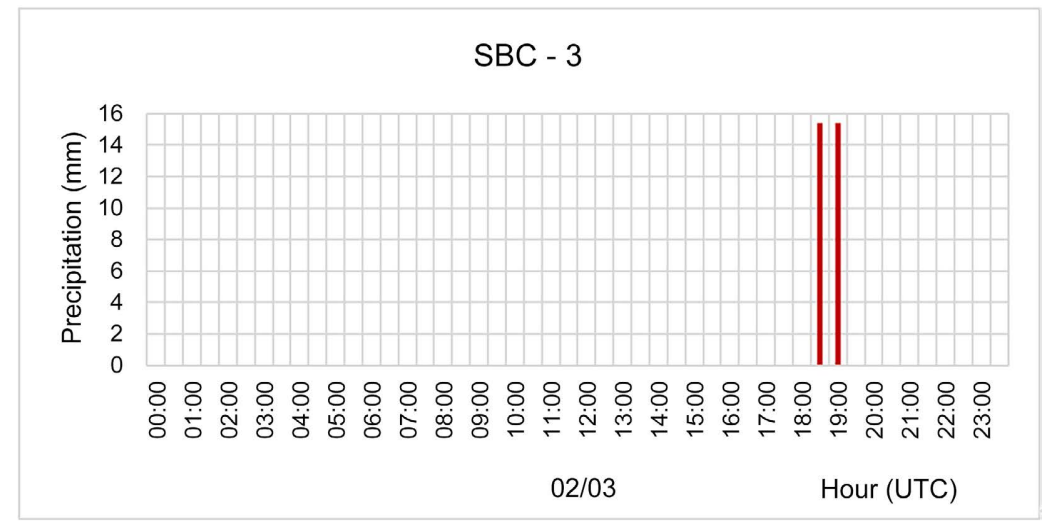

(c)

Figure 8. Occurrence of rain in SBC-1 (a) on 11 and 12/01/2010; in SBC-2 (b) on $01 / 26 / 2010$; and SBC-3 (c) on $02 / 03 / 2010$. SOAS precipitation estimates every 30 minutes. 


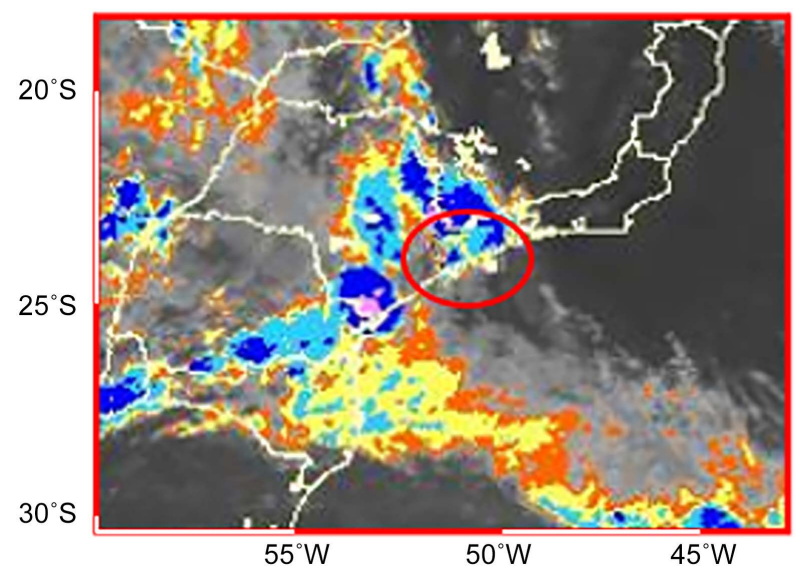

(a)

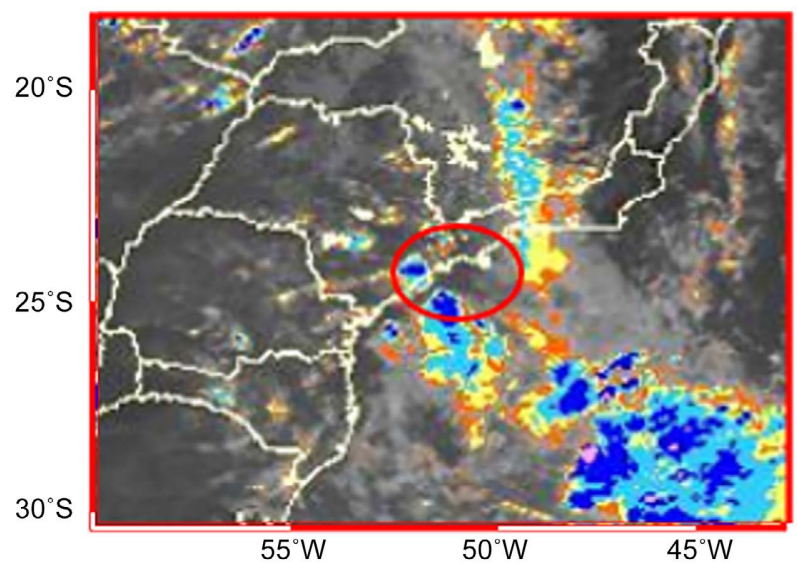

(b)

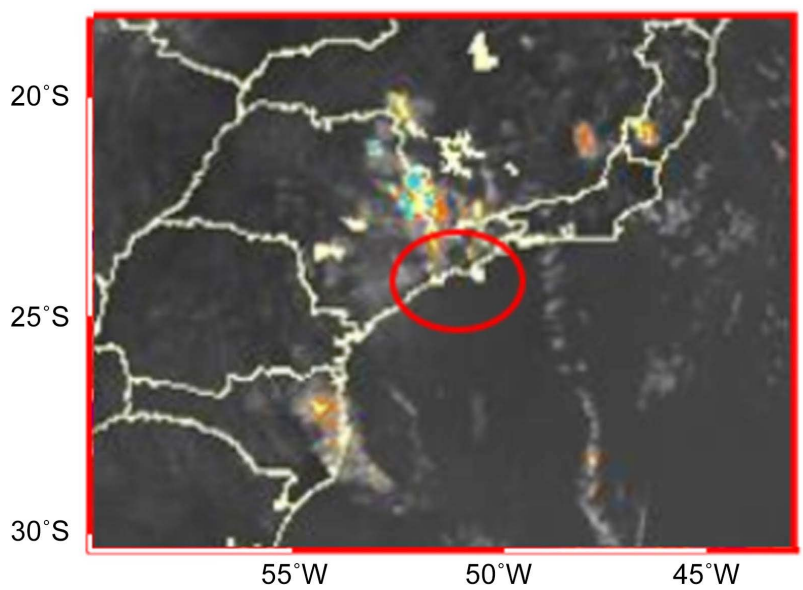

(c)

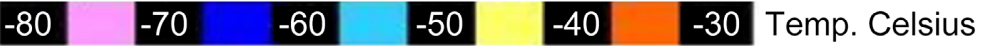

Figure 9. SBC-1, 11/01 at 2030 UTC (a); SBC-2, 26/01 at 1530 UTC (b) and SBC-3 03/02 at 1830 UTC (c). Source: Adapted [21].

It is observed that the local rainy season (SOAS) is contained in the rainy season observed by the SPWR. 
The precipitating systems acting in $\mathrm{SBC}-1$ are the Amazonian humidity which moves to the Southeast region and a CF approaching and associated with an instability line. In SBC-2 convective systems move from the Midwest to the Southeast and associate with a CF. And in SBC-3 few clouds and some instability are configuring a few clouds and some instability are configuring an IC. The estimated volumes of accumulated precipitation at the end of the rain are documented in Table 6 and shown in Figure 10 and Figure 11.

A summary of the results obtained for each erosion event was prepared, shown in Table 7.

Table 6. Estimated volumes accumulated during rainfall measured by SPWR and SOAS.

\begin{tabular}{ccc}
\hline Location & SPWR rainfall estimation $(\mathrm{mm})$ & SOAS rainfall estimation $(\mathrm{mm})$ \\
\hline SBC-1 & $10<\mathrm{r}<40$ & $35<\mathrm{r}<45$ \\
SBC-2 & $30<\mathrm{r}<75$ & $30<\mathrm{r}<70$ \\
SBC-3 & $5<\mathrm{r}<20$ & $30<\mathrm{r}<40$ \\
\hline
\end{tabular}

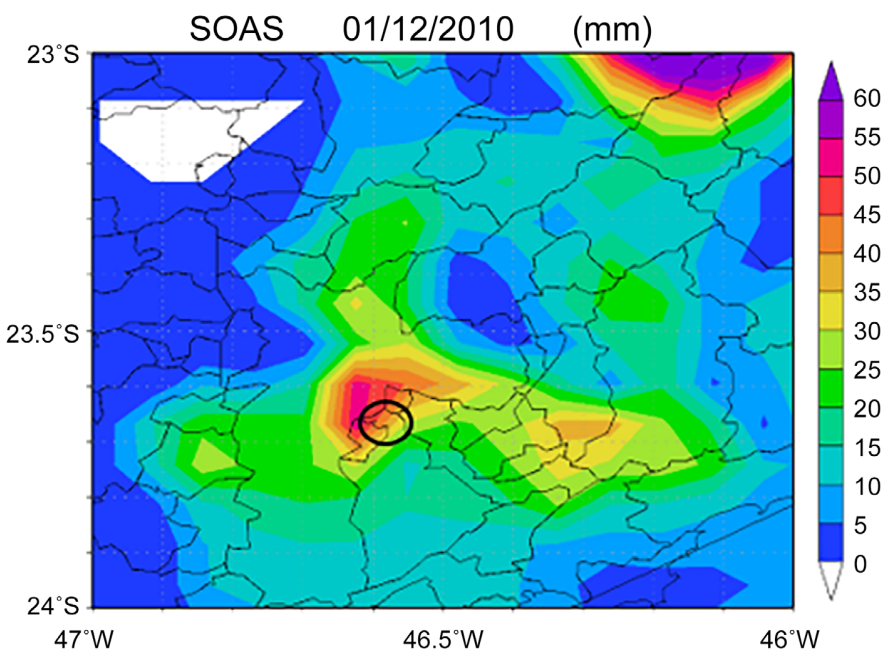

(a)

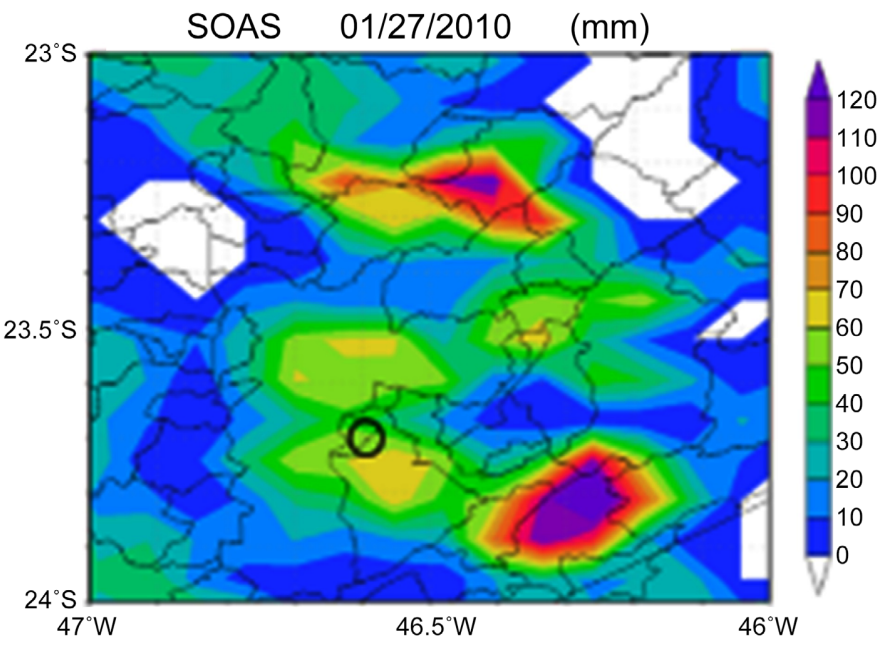

(b) 


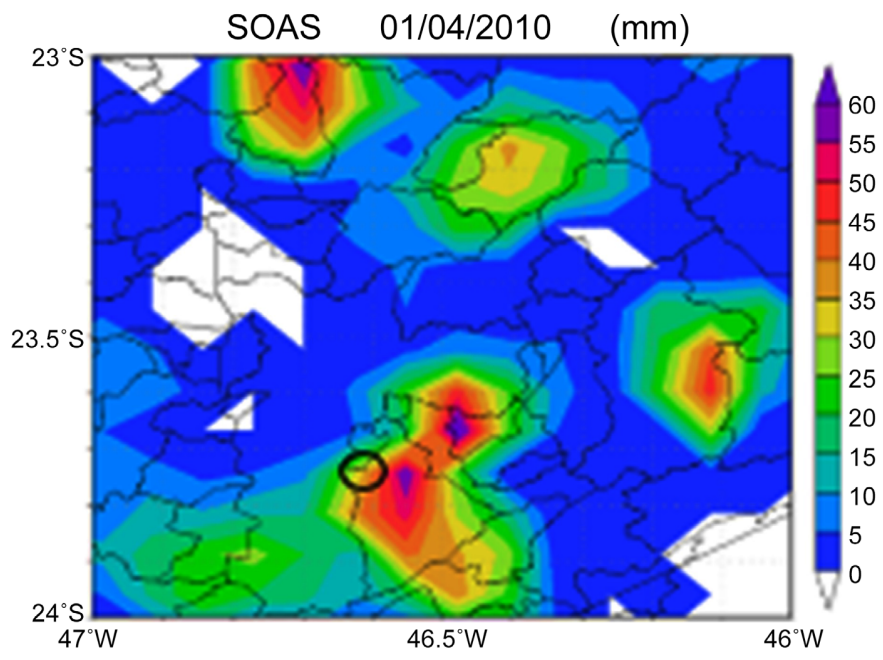

(c)

Figure 10. Images of ANOBES accumulated precipitation estimates from $7 \mathrm{~h}(\mathrm{HL})$ of one day to $7 \mathrm{~h}$ (HL) of the previous day. The estimation system, day, month, year, hour, and precipitation unit are indicated in the image. The geopolitical and geographic contours are also indicated. The arrow indicates the area of the erosion event. The color scale indicates the precipitation unit (mm). (a) SBC-1; (b) SBC-2; and (c) SBC-3.

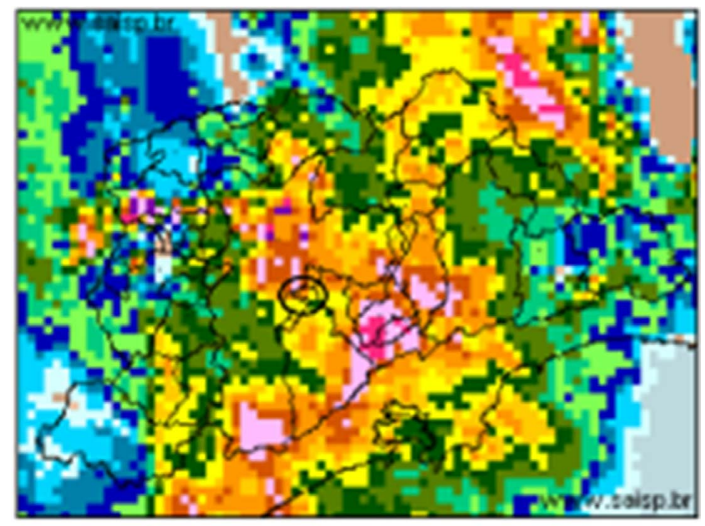

01/11/2010 1420 - 01/12/20100630

(a)

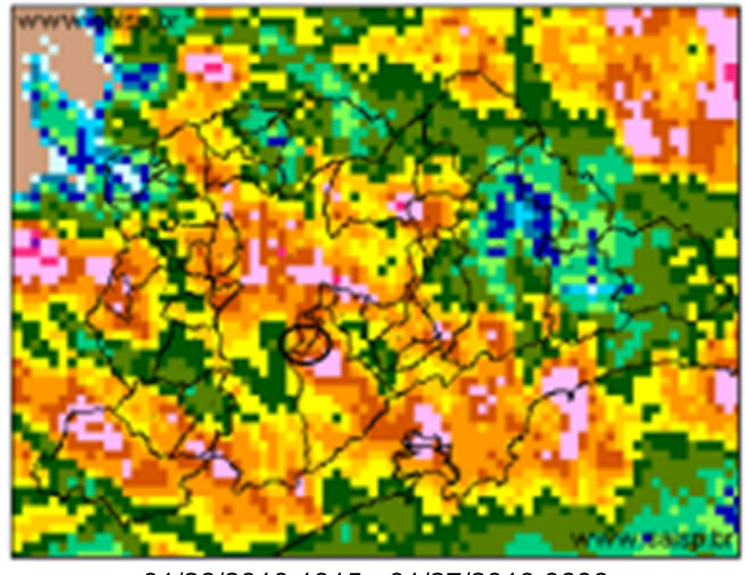

01/26/2010 1315 - 01/27/20100606

(b) 


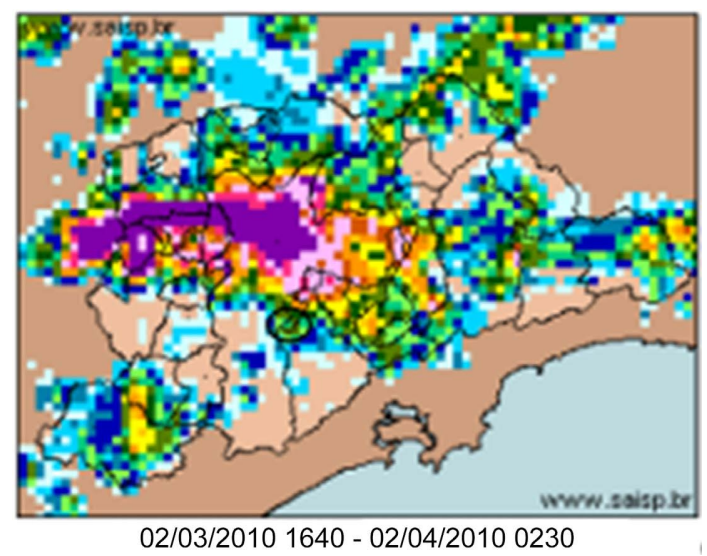

(c)

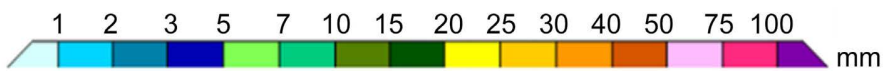

Figure 11. Estimates of accumulated precipitation values by the SPWR in rainfall events. Indicated geopolitical and geographic contours. The black circumference indicates the location of the rain event. (a) SBC-1; (b) SBC-2; and (c) SBC-3.

Table 7. Summary of results obtained for each erosion event.

\begin{tabular}{|c|c|c|c|c|c|c|c|c|c|}
\hline \multirow[b]{3}{*}{ Rain } & \multicolumn{9}{|c|}{ Location } \\
\hline & \multicolumn{3}{|c|}{ SBC-1 } & \multicolumn{3}{|c|}{ SBC-2 } & \multicolumn{3}{|c|}{ SBC-3 } \\
\hline & $\begin{array}{l}\text { Start } \\
\text { day }\end{array}$ & $\begin{array}{l}\text { Hour } \\
\text { (UTC) }\end{array}$ & $\begin{array}{l}\text { Duration } \\
\text { (h) }\end{array}$ & Start day & $\begin{array}{l}\text { Hour } \\
\text { (UTC) }\end{array}$ & Duration (h) & Start day & $\begin{array}{l}\text { Hour } \\
\text { (UTC) }\end{array}$ & $\begin{array}{c}\text { Duration } \\
\text { (h) }\end{array}$ \\
\hline Accumulated & \multirow{2}{*}{$01 / 11$} & 1418 & 16.0 & \multirow{2}{*}{$01 / 26$} & 1314 & 17.0 & \multirow{2}{*}{$02 / 03$} & 1742 & 6.5 \\
\hline Local & & 2030 & 7.5 & & 1230 & 11.5 & & 1830 & 1.0 \\
\hline Accumulated SPWR & \multicolumn{3}{|c|}{$10<\mathrm{a}<40 \mathrm{~mm}$} & \multicolumn{3}{|c|}{$30<\mathrm{a}<75 \mathrm{~mm}$} & \multicolumn{3}{|c|}{$05<\mathrm{a}<20 \mathrm{~mm}$} \\
\hline AccumulatedSOAS & \multicolumn{3}{|c|}{$35<\mathrm{a}<45 \mathrm{~mm}$} & \multicolumn{3}{|c|}{$30<\mathrm{a}<70 \mathrm{~mm}$} & \multicolumn{3}{|c|}{$30<\mathrm{a}<40 \mathrm{~mm}$} \\
\hline Precipitating Systems & \multicolumn{3}{|c|}{$\mathrm{CF}$ and IL } & \multicolumn{3}{|c|}{ convective systems andCF } & \multicolumn{3}{|c|}{ IC } \\
\hline $\begin{array}{l}\text { Accumulated in the } 30 \\
\text { days prior toerosion }\end{array}$ & \multicolumn{3}{|c|}{$\begin{array}{c}\text { SOAS }-369.7 \mathrm{~mm} \\
\text { CMORPH-225.7 mm }\end{array}$} & \multicolumn{3}{|c|}{$\begin{array}{c}\text { SOAS }-543.8 \mathrm{~mm} \\
\text { CMORPH }-487.3 \mathrm{~mm}\end{array}$} & \multicolumn{3}{|c|}{$\begin{array}{c}\text { SOAS }-742.5 \mathrm{~mm} \\
\text { CMORPH-416.8 mm }\end{array}$} \\
\hline
\end{tabular}

\subsection{Climatological Analysis}

For the climatological analysis, the monthly estimated values, in the years 2009 and 2010, were compared with the values measured in the USP WS. The geographic coordinates, Table 1, were used to determine the CMORPH cell and obtain the estimate of daily accumulated precipitation. With the daily estimate, Table 8 was elaborated with the monthly and annual precipitation estimate, in the years 2009 and 2010. A comparison was made with the USP WS values.

For the climatological analysis, the monthly estimated values, in the years 2009 and 2010, were compared with the values measured in the USP WS. The geographic coordinates, Table 1, were used to determine the CMORPH cell and obtain the daily accumulated precipitation estimate. With the daily estimate, Table 8 was elaborated with the monthly and annual precipitation estimate, in the year of occurrence of the erosion events and in the previous year (2009 and 2010). A comparison was made with the USP WS climatological series. 
Table 8. Estimated accumulated precipitation for the years 2009 and 2010 in the 3 selected erosion events and the USP WS.

\begin{tabular}{ccccccccc}
\hline & USP WS & SBC-1 & SBC-2 & SBC-3 & USP WS & SBC-1 & SBC-2 & SBC-3 \\
& 2009 & 2009 & 2009 & 2009 & 2010 & 2010 & 2010 & 2010 \\
\hline Jan & 233.9 & 199.3 & 151.1 & 171.1 & 653.2 & 716.8 & 557.7 & 719.5 \\
Feb & 219.2 & 107.0 & 186.1 & 88.9 & 394.0 & 190.8 & 297.9 & 236.2 \\
Mar & 245.9 & 95.2 & 186.6 & 184.5 & 147.6 & 172.3 & 177.6 & 166.5 \\
Apr & 52.3 & 120.5 & 55.5 & 64.9 & 130.4 & 88.8 & 90.7 & 76.6 \\
Mai & 56.2 & 53.8 & 58.3 & 39.8 & 81.1 & 74.8 & 64.6 & 68.9 \\
Jun & 41.7 & 30.2 & 22.9 & 24.8 & 12.7 & 8.4 & 12.8 & 16.5 \\
Jul & 200.0 & 199.7 & 204.7 & 199.7 & 89.6 & 88.7 & 79.1 & 83.7 \\
Aug & 50.5 & 58.8 & 46.3 & 58.1 & 3.7 & 2.9 & 10.3 & 17.0 \\
Sep & 202.9 & 293.8 & 178.0 & 210.8 & 96.7 & 108.0 & 92.2 & 114.2 \\
Oct & 138.0 & 145.9 & 115.8 & 138.2 & 76.6 & 68.3 & 75.5 & 75.5 \\
Nov & 234.4 & 172.8 & 124.7 & 116.4 & 159.2 & 105.4 & 22.3 & 81.1 \\
Dec & 208.6 & 234.3 & 290.0 & 271.1 & 280.6 & 336.7 & 232.2 & 262.7 \\
Total & 1883.6 & 1711.3 & 1619.6 & 1568.3 & 2125.4 & 1961.8 & 1712.9 & 1918.4 \\
\hline
\end{tabular}

Analyzing Table 8, it can be seen that at the sites of erosion events, rainfall is above the USP WS values in December 2009 and January 2010. Thus, in December 2009, the soil is well saturated and the high rainfall values in January and February 2010 resulted in erosion events. It appears that 2010 was a very rainy year in these places.

Now that it has been shown that using the applied methodology it is possible to determine the day and time of the probable rain that caused the erosion event. The idea is to apply this methodology to other erosion event records that for some reason do not have the SPWR rain report or satellite images available on the rain date, but have CMORPH and SOAS data. And in this way, try to establish other situations that anticipate the conditions of erosion risk.

\section{Conclusion}

For the 3 events analyzed, it is noted that the rains occurred from 1 to 3 days before the erosion event was registered. It was possible to determine the date and time of rain by the CMORPH and SOAS methods and quantify the values of estimated accumulated precipitation. The values of the estimates below were obtained by the SOAS method. The maximum precipitation in 30 minutes ranged from $10 \mathrm{~mm}$ to $19.8 \mathrm{~mm}$. The estimate of daily precipitation ranged from 30.8 $\mathrm{mm}$ to $69.5 \mathrm{~mm}$ on the day of the rain event that caused the erosion event. And the estimate of precipitation in the period that precedes 30 days to the erosion event varied between $369.7 \mathrm{~mm}$ and $742.5 \mathrm{~mm}$. It was identified that there are erosion events associated with normal rainfall volumes and events associated with very high rainfall volumes. Saturated soil is more prone to the occurrence 
of erosion events. Meteorological analysis of rainfall events indicates that precipitation systems are associated with CF, IL, and IC. The results show that the estimated precipitation values by the SOAS method are greater than the USP WS climatological series in December 2009 and January 2010, and indicate a rainy year. It can be seen that with a month of high precipitation estimate values, we can expect an erosion event if extreme rains continue to occur. Thus, it can be a risk alert for the place. With the method used, it was possible to relate the data obtained by the CMORPH and SOAS methods with the events detected by meteorological radar and satellite images. Data from the CMORPH and SOAS methods are available for the Brazilian territory, thus, the method described can be used for the study of rainfall occurring in remote locations.

\section{Acknowledgements}

The author would to thank M.Sc. Kleber Rocha for providing the SPWR archives and Dr. Fabio Augusto Gomes Vieira Reis for providing the Civil Defense Erosion files used in this research. M.C.S.L was sponsored by Fundação Coordenação de Aperfeiçoamento de Pessoal de Nível Superior (CAPES). A.J.P.F was sponsored by Conselho Nacional de Desenvolvimento Científico e |Tecnológico (CNPq) under grant 302349/2017-6.

\section{Conflicts of Interest}

The authors declare no conflicts of interest regarding the publication of this paper.

\section{References}

[1] Corghi, F. and Giacheti, H. (2006) Processos erosivos na Área Urbana de Bauru-SP. VI Simpósio Nacional de Geomorfologia (SINAGEO). Anais de Trabalhos Completos, Goiás/Goiânia, 1, 227. http://lsie.unb.br/ugb/sinageo/6/9/386.pdf

[2] Zamuner, L.D., De Nóbrega, M.T. and Martoni, A.M. (2002) A urbanização e o desencadeamento de processos erosivos em área de preservação ambiental na cidade de Maringá, Estado do Paraná. Acta Scientiarum. Technology, 24, 1793-1800.

[3] De Jesus, A.S. and De Carvalho, J.C. (2017) Processos erosivos em área urbana e as implicações na qualidade de vida. Boletim Goiano de Geografia, 37, 1-17. https://dialnet.unirioja.es/servlet/articulo? codigo $=5906334$ https://doi.org/10.5216/bgg.v37i1.46239

[4] Coelho, V.H.R., et al. (2014) Dinâmica do uso e ocupação do solo em uma bacia hidrográfica do semiárido brasileiro. Revista Brasileira de Engenharia Agrícola e Ambiental, 18, 64-72. https://doi.org/10.1590/S1415-43662014000100009

[5] Hillel, D. (2004) Introduction to Environmental Soil Physics. Elsevier, Amsterdam. https://books.google.com.br/books?hl=pt-BR\&lr=\&id=qK7zzLIUEloC\&oi=fnd\&pg $=$ PP2\&dq=HILLEL,+Daniel.+Introduction+to+environmental+soil+physics. + Elsev ier, +2004 .\&ots=-JemL7FyAE\&sig=NAD5aFhFxBK4y84uhXTBkIssjdM\&redir esc $=$ $\mathrm{y} \# \mathrm{v}=$ onepage $\& \mathrm{q}=$ HILLEL\%2C\%20Daniel.\%20Introduction $\% 20$ to\%20nvironmenta 1\%20soil\%20physics.\%20Elsevier\%2C\%202004.\&f=false

[6] Guerra, A.T., Da Silva, A.S. and Botelho, R.G.M. (2007) Erosão e conservação dos solos: Conceitos, temas e aplicações. Bertrand, Brasil. 
[7] Dyonisio, H.A.F. (2010) Erosão hídrica: Suscetibilidade do solo. Revista Eletrônica Thesis, 2010, 15-25. http://www.cantareira.br/thesis2/ed 13/2 hidrica.pdf

[8] Johannsen, L.L., et al. (2020) Impact of Disdrometer Types on Rainfall Erosivity Estimation. Water, 12, 963. https://doi.org/10.3390/w12040963

[9] Bertoni, J. and Neto, F.L. (2005) Conservação do solo. Ícone, São Paulo. http://www.sidalc.net/cgi-bin/wxis.exe/?IsisScript=cidca.xis\&method=post\&format $\underline{\mathrm{o}=2 \& \text { cantidad }=1 \text { \&expresion }=\mathrm{mfn}=003008}$

[10] Brito, A.O., Martins, I.S. and Aicha, N.N. (2012) Estudos da erosão urbana no Distrito Federal. Revista Científica Eletrônica de Engenharia Florestal, Garça, 20, 85-92. http://faef.revista.inf.br/imagens arquivos/arquivos destaque/mWwAkAhB70T6tP L 2013-4-29-16-6-14.pdf

[11] Salviano, M.F., Pereira Filho, A.J. and Vemado, F. (2021) TOPMODEL Hydrometeorological Modeling with Rain Gauge Data Integrated by High-Resolution Satellite Estimates. A Case Study in Muriaé River Basin, Brazil. Atmospheric and Climate Sciences, 11, 486-507. https://doi.org/10.4236/acs.2021.113029

[12] Silva, F.D.D.S., Pereira Filho, A.J. and Hallak, R. (2009) Classificação de sistemas meteorológicos e comparação da precipitação estimada pelo radar e medida pela rede telemétrica na Bacia Hidrográfica do Alto Tietê. Revista Brasileira de Meteorologia, 24, 292-307. https://doi.org/10.1590/S0102-77862009000300004

[13] Ihadua, I.M.T.J. and Pereira Filho, A.J. (2021) On Thunderstorm Microphysics under Urban Heat Island, Sea Breeze, and Cold Front Effects in the Metropolitan Area of São Paulo, Brazil. Atmospheric and Climate Sciences, 11, 614-643. https://doi.org/10.4236/acs.2021.113037

[14] Vemado, F. and Pereira Filho, A.J. (2016) Severe Weather Caused by Heat Island and Sea Breeze Effects in the Metropolitan Area of São Paulo, Brazil. Advances in Meteorology, 2016, Article ID: 8364134. https://doi.org/10.1155/2016/8364134

[15] Cavalcanti, I.F.A., et al. (2009) Clima e Tempo no Brasil. Vol. 463, Oficina de Texto, São Paulo.

[16] Sun, R.C., et al. (2016) Evaluation of the Latest Satellite-Gauge Precipitation Products and Their Hydrologic Applications over the Huaihe River Basin. Journal of $\mathrm{Hy}$ drology, 536, 302-319. https://doi.org/10.1155/2016/8364134

[17] Pereira Filho, A.J., Vemado, F., Vemado, G., Reis, F.A.G.V., Giordano, L.C., Cerri, R.I., Santos, C.C., Lopes, E.S.S., Gramani, M.F., Ogura, A.T., Zaine, J.E., Cerri, L.E.S., Augusto Filho, O., D’Affonseca, F.M. and Amaral, C.S. (2018) A Step towards Integrating CMORPH Precipitation Estimation with Rain Gauge Measurements. Advances in Meteorology, 2018, Article ID: 2095304.

https://doi.org/10.1155/2018/2095304

[18] IAG/USP (2014) Boletim climatológico anual da Estação Meteorológica do IAG/ USP, Seção Técnica de Serviços Meteorológicos, v. 16.

[19] Rocha Filho, K., Conde, F. and Andrioli, C.P. (2013) Correção em tempo real da precipitação estimada por um radar meteorológico com uma rede de superfície. XX Simpósio Brasileiro De Recursos Hídricos, Bento Gonçalves, RS, BRAZIL, ABRH, Associação Brasileira de Recursos Hídricos.

https://abrh.s3.sa-east-1.amazonaws.com/Sumarios/155/d765c62638a979c5935494b fdb7eb760 c549efbade76ad5bf58783a9d3057117.pdf

[20] Barbosa, H.A., Ertük, A.G. and Silva, L.R.M. (2012) Using the Meteosat-9 Images to the Detection of Deep Convective Systems in Brazil. Hyperspectral Remote Sensing, 2, 69-82. https://doi.org/10.5935/2237-2202.20120007

[21] Adaptado satélite CPET-INPE. Copyright 2010-2012 EUMETSAT. http://satelite.cptec.inpe.br/acervo/meteosat.formulario.logic?i=br 


\section{Abbreviations}

CMORPH-Climate Prediction Center Morphing Method

SOAS-Statistical Objective Analysis method

NWA-National Water Agency

MRSP-Metropolitan region of Sao Paulo

IC-Isolated Convection

SB-Sea Breeze

IL-Instability Lines

SPB-Scattered Precipitation Bands

CD-Cold Fronts

SPWR-São Paulo Weather Radar

USP WS-USP Weather Station 